ISSN: 2302-8556

\title{
Pengaruh Penghindaran Pajak pada Nilai Perusahaan dengan Kebijakan Hutang Sebagai Variabel Pemoderasi
}

\author{
Ni Wayan Sarasati Pramudia Wanami $\mathbf{P}^{1}$ \\ Ni Ketut Lely Aryani Merkusiwati ${ }^{2}$
}

\author{
${ }^{1,2}$ Fakultas Ekonomi dan Bisnis Universitas Udayana (Unud), Bali, Indonesia \\ e-mail: sarasatiwanami36@gmail.com
}

\begin{abstract}
ABSTRAK
Tindakan penghindaran pajak merupakan suatu cara dalam melakukan manajemen pajak, tindakan yang dilakukan oleh perusahaan tersebut akan memberikan sinyal kepada investor dan dapat berpengaruh pada nilai perusahaan, dimana selanjutnya kebijakan hutang yang dimiliki oleh suatu perusahaan dapat pula memengaruhi penilaian suatu perusahaan oleh investor. Tujuan dari penelitian ini adalah untuk mengetahui bagaimana pengaruh penghindaran pajak terhadap nilai perusahaan dengan kebijakan hutang sebagai variabel pemoderasi. Penelitian ini dilakukan pada perusahaan manufaktur yang terdaftar di Bursa Efek Indonesia. Jumlah sampel yang diambil sebanyak 182 perusahaan, dengan metode purposive sampling. Pengumpulan data dilakukan melalui observasi non partisipan. Teknik analisis yang digunakan adalah moderated regression analysis. Berdasarkan hasil analisis ditemukan bahwa penghindaran pajak berpengaruh positif pada nilai perusahaan. Kebijakan hutang perusahaan dapat memoderasi dan memerkuat pengaruh penghindaran pajak pada nilai perusahaan.
\end{abstract}

Kata Kunci: Nilai perusahaan, penghindaran pajak, kebijakan hutang.

\begin{abstract}
Tax avoidance is one of the way to do the tax management, it can give a signal to the investors and make an impact to the firm value. The debt policy of a firm also can influence the investors's assessment to the firm. This research has an objective to obtain empirical evidence about the impact of tax avoidance in firm value with debt policy as the moderating variabel. The research was conducted at manufactur company which listed in Indonesian Stock Exchange in 2013-2017 using purposive sampling method as sample selection method. The number of samples is 182 companies. Data analysis technique used is Moderated Regression Analysis (MRA). The result of this analysis is tax avoidance positively affect the firm value and the debt policy strengthen the impact of tax avoidance on the firm value.
\end{abstract}

Keywords: Firm value, tax avoidance, debt policy.

\section{PENDAHULUAN}

Perusahaan merupakan suatu unit bisnis yang mempunyai tujuan untuk memeroleh laba atau keuntungan dari aktivitas bisnis yang dilakukan. Setiap perusahaan 
Ni Wayan Sarasati Pramudia Wanami P. dan Ni Ketut Lely Aryani Merkusiawati. Pengaruh ...

memerlukan modal atau dana dalam menjalankan aktivitas yang diinginkan. Sumber dana perusahaan dapat berasal dari modal sendiri dalam bentuk laba ditahan, menggunakan hutang ataupun dengan menggunakan ekuitas (saham) dengan cara menerbitkan saham baru (Midiastuty dkk., 2017). Ketika suatu perusahaan memeroleh modal dari saham, perusahaan akan berusaha untuk meningkatkan kinerja agar dapat memaksimumkan kemakmuran pemegang saham melalui memaksimalkan nilai perusahaan. Nilai perusahaan diartikan sebagai harga yang bersedia dibayar oleh calon investor seandainya suatu perusahaan akan dijual.

Berdasarkan data nilai perusahaan Penanam Modal Asing (PMA) yang terdaftar di Bursa Efek Indonesia (BEI) dari tahun 2012 sampai dengan tahun 2016 bahwa fenomena yang terjadi menunjukan perubahan nilai perusahaan yang befluktuasi dan menggambarkan bahwa perusahaan memiliki kinerja yang berubah ubah (tidak konsisten). Contohnya nilai perusahaan pada PT Sepatu Bata Tbk (BATA) pada tahun 2012 sebesar 1.68 naik pada tahun 2013 menjadi 2.44 kemudian mengalami penurunan berturut-turut sebesar 2.33 pada tahun $2014,1.75$ pada tahun 2015 dan 1.58 pada tahun 2016. Sama halnya dengan PT Indo Kordsa Tbk (BRAM) nilai perusahaan pada tahun 2012 sebesar 0.87 menurun pada tahun 2013 menjadi 0.67 kemudian pada tahun 2014 naik menjadi 1.01 dan menurun kembali pada tahun 2015 menjadi 0.90 dan pada tahun 2016 naik menjadi 1.09. Sedangkan nilai perusahaan pada PT Multi Bintang Indonesia (MLBI) pada tahun 2012 sebesar 14.26 naik pada tahun 2013 menjadi 14.63 dan turun menjadi 12.04 pada tahun $2014,8.86$ pada tahun 2015 dan naik kembali pada tahun 2016 menjadi 11.52. 
ISSN: 2302-8556

Berfluktuasinya nilai perusahaan menggambarkan bahwa harga saham perusahaan tidak stabil. Perusahaan yang bagus tercermin dari harga saham yang stabil dan meningkat. Harga saham yang tinggi membuat perusahaan bernilai tinggi dan memengaruhi kepercayan pasar terhadap kinerja perusahaan saat ini dan prospek perusahaan di masa depan, sehingga nilai perusahaan menjadi sesuatu yang sangat penting dalam transaksi investasi (Ampriyanti \& Lely, 2016). Berdasarkan teori sinyal, nilai perusahaan yang stabil dan meningkat memberikan dampak bagi pemegang saham untuk tetap mempertahankan modalnya serta memberikan sinyal bagi para calon investor untuk berinvestasi pada perusahaan tersebut. Untuk menarik kepercayaan investor, manajemen berupaya meningkatkan nilai perusahaan, salah satu cara yang ditempuh yaitu dengan meminimalkan pembayaran beban pajak perusahaan melalui penghindaran pajak (tax avoidance) (Ampriyanti \& Lely, 2016). Dengan melakukan penghindaran pajak maka perusahaan telah mentransfer kekayaan dari pemerintah ke pemegang saham sehingga berdampak pada meningkatnya nilai perusahaan (Chen, et al., 2016).

Berdasarkan teori keagenan, perusaahaan dan otoritas pajak memiliki kepentingan yang berbeda dimana perusahaan memiliki kepentingan dalam optimalisasi penghematan beban pajak perusahaan karena manajemen memiliki pandangan bahwa laba bersih yang diperoleh perusahaan akan berkurang akibat adanya pembayaran pajak, sedangkan otoritas pajak memiliki kepentingan untuk melakukan optimalisasi atas penerimaan pajak karena pajak merupakan sumber 
Ni Wayan Sarasati Pramudia Wanami P. dan Ni Ketut Lely Aryani Merkusiawati. Pengaruh ...

penerimaan negara yang utama (Ampriyanti \& Lely, 2016). Teori Keagensian yang menyatakan bahwa Pendelegasian wewenang yang dilakukan pihak prinsipal kepada agen akan menuntut agen untuk memberikan kinerjanya sebaik mungkin agar dapat meningkatkan performa perusahaannya. Oleh karena itu, manajemen berusaha untuk mengelola keuangan perusahaannya dengan baik dan efisien. Salah satu langkah efisiensi yang dilakukan yaitu dengan meminimalkan beban pajak, yang dianggap dapat mengurangi kemampuan ekonomis perusahaan. Sehingga manajemen termotivasi untuk melakukan penghindaran pajak agar dapat meminimalkan beban perusahaan

Jika banyak perusahaan yang melakukan penghindaran pajak maka penerimaan negara yang bersumber dari pajak yang seharusnya diperoleh oleh negara menjadi tidak maksimal. Berikut gambaran antara target dengan realisasi penerimaan pajak negara 6 tahun terakhir.

Tabel 1.

Target dan Realisasi Penerimaan Pajak

\begin{tabular}{|c|c|c|c|c|c|}
\hline Tahun & & Target & & Realisasi & Presentase \\
\hline 2011 & Rp. & 879 triliun & Rp. & 874 triliun & 99,4 \\
\hline 2012 & Rp. & 1.016 triliun & Rp. & 981 triliun & 96,4 \\
\hline 2013 & Rp. & 1.148 triliun & Rp. & 1.077 triliun & 93,8 \\
\hline 2014 & $\mathrm{Rp}$. & 1.246 triliun & Rp. & 1.143 triliun & 91,7 \\
\hline 2015 & Rp. & 1.489 triliun & Rp. & 1.235 triliun & 82,9 \\
\hline 2016 & Rp. & 1.555 triliun & Rp. & 1.360 triliun & 87,4 \\
\hline
\end{tabular}

Sumber: Kementrian Keuangan Republik Indonesia, 2018

Berdasarkan Tabel 1.1, dari tahun 2012 hingga 2015 telah terjadi penurunan realisasi pajak, dimana pada tahun 2013 dan 2015 telah terjadi penurunan realisasi pajak yang paling besar yaitu di tahun 2013 terjadi penurunan sebesar 2,6 persen dan di tahun 
ISSN: 2302-8556

2015 terjadi penurunan realisasi sebesar 8,8 persen. Perusahaan manufaktur memiliki aktivitas usaha yang sebagian besar berhubungan dengan perpajakan, selain itu perusahaan manufaktur juga merupakan penyumbang penerimaan pajak negara terbesar disamping industri pertambangan, keuangan dan perkebunan (Kementrian Keuangan Republik Indonesia, 2018). Perusahaan manufaktur beberapa kali masuk sebagai wajib pajak yang difokuskan dalam daftar pemeriksaan Direktorat Jenderal Pajak, karena berdasarkan survei pada tahun 2012 terdapat 2000 perusahaan penanaman modal asing di Indonesia yang bergerak dibidang manufaktur tidak membayar Pajak Penghasilan (PPh) Badan Pasal 25 dan pasal 29 karena alasan merugi. Perusahaan tersebut menggunakan tiga modus utama yaitu transfer pricing, memanfaatkan insentif pajak (tax holiday) dan mengganti nama perusahaan agar dapat menghindar dari kewajiban menyetor pajak (Cahyono, dkk., 2016).

Hasil penelitian sebelumnya mengenai pengaruh penghindaran pajak pada nilai perusahaan tidak konsisten. Prasiwi (2015), Anggoro \& Septiani (2015), Kurniawan \& Syafruddin (2017) mendapatkan hasil bahwa penghindaran pajak berpengaruh positif pada nilai perusahaan. Penelitian Ampriyanti \& Lely (2016), Partha \& Noviari (2016), dan Tarihoran (2016) menemukan tindakan penghindaran pajak berpengaruh negatif pada nilai perusahaan.Penghindaran pajak jika didefinisikan lebih luas selain untuk meningkatkan laba juga diharapkan mampu meningkatkan nilai perusahaan (Prasiwi, 2015). Informasi laba bersih yang tinggi akibat dari aktivitas penghindaran pajak diharapkan mampu menjadi sinyal positif 
Ni Wayan Sarasati Pramudia Wanami P. dan Ni Ketut Lely Aryani Merkusiawati. Pengaruh ...

bagi investor sehingga berdampak positif pada nilai perusahaan yang tercermin dari kenaikan nilai sahamnya dipasar modal.

Hasil lainnya mengatakan bahwa praktik penghindaran pajak juga dapat menurunkan nilai perusahaan, penghindaran pajak tidak selalu diinginkan oleh pemegang saham karena adanya gabungan biaya, yang meliputi biaya yang berkaitan langsung dan tidak langsung dengan penghindaran pajak (Ampriyanti \& Lely, 2016). Berdasarkan adanya inkonsistensi hasil dari penelitian empiris sebelumnya, maka peneliti tertarik untuk melakukan penelitian kembali tentang pengaruh dari penghindaran pajak pada nilai perusahaan dengan menambahkan kebijakan hutang sebagai variabel pemoderasi. Kebijakan hutang merupakan keputusan manajemen untuk mengelola modal dalam perusahaan yang diperoleh dari pihak eksternal dalam bentuk pinjaman yang dapat ditunjukkan oleh total hutang perusahaan dibagi dengan total modal (Endraswati, 2013).

Alasan peneliti menambahkan kebijakan hutang sebagai variabel pemoderasi, karena kebijakan hutang suatu perusahaan dapat menunjukan instrumen penghindaran pajak yang digunakan oleh perusahaan adalah dengan memaksimalkan biaya pengurang pajak (deductible expense) yaitu biaya hutang. Salah satu cara memanfaatkan deductible expense adalah dengan biaya bunga. (Horne \& John M Wachowicz, 2009:461) menyatakan bahwa manfaat daripada hutang bagi pajak perusahaan adalah adanya biaya bunga itu sendiri yang akan menjadi biaya pengurang atau deductible expense bagi perusahaan yang menggunakan hutang dalam struktur modalnya. PMK No. 169/PMK.010/2015 (Kementrian Keuangan Republik 
ISSN: 2302-8556

E-Jurnal Akuntansi Universitas Udayana

Vol.27.1.April (2019):446-474

Indonesia, 2015) merupakan peraturan di Indonesia yang mengakui beban bunga sebagai deductible expense. Peraturan ini mengatur bahwa bunga hutang yang dapat diakui sebagai biaya adalah sebesar bunga atas hutang yang perbandingannya terhadap modal, yaitu setinggi-tingginya empat banding satu (4:1).

Berdasarkan teori oleh Modigliani Miller (1963) dalam Trade Off Theory Penggunaan hutang akan meningkatkan nilai perusahaan karena biaya bunga hutang adalah biaya yang mengurangi pembayaran pajak, hal tersebut selanjutnya memengaruhi kebijakan hutang suatu perusahaan. Hal ini ditunjukan oleh hasil penelitian-penelitian terdahulu, menurut Jensen (1986) dalam Endraswati (2013) penggunaan hutang dapat digunakan untuk mengendalikan penggunaan free cash flow secara berlebihan oleh manajemen, sehingga menghindari investasi yang sia-sia dan dapat meningkatkan nilai perusahaan serta berdasarkan penelitian oleh Midiastuty dkk. (2017) bagi perusahaan yang sangat fokus melakukan penghindaran pajak dengan menggunakan deductible expense yaitu dengan biaya bunga, umumnya akan bersedia memiliki leverage atau tingkat hutang yang lebih tinggi pajak efektif tunai yang lebih rendah, sehingga muncul kecenderungan bagi perusahaan untuk melakukan pembiayaan kembali hutang pada tahun selanjutnya sehingga dapat manfaatkan dari insentif pajak yang lebih besar dan meningkatkan nilai perusahaan (Midiastuty dkk., 2017).

Berdasarkan latar belakang diatas, maka peneliti mengangkat dua rumusan masalah, yaitu apakah penghindaran pajak berpengaruh pada nilai perusahaan serta apakah kebijakan hutang dapat memperkuat pengaruh penghindaran pajak pada nilai 
Ni Wayan Sarasati Pramudia Wanami P. dan Ni Ketut Lely Aryani Merkusiawati. Pengaruh ...

perusahaan. Adapun tujuan penelitian ini adalah untuk mendapatkan bukti empiris mengenai pengaruh penghindaran pajak pada nilai perusahaan dan untuk mendapatkan bukti empiris mengenai peran kebijakan hutang dalam memoderasi pengaruh penghindaran pajak pada nilai perusahaan. Secara teoritis, penelitian ini diharapkan bermanfaat untuk dapat menambah bukti empiris tentang studi yang membahas pengaruh penghindaran pajak pada nilai perusahaan dengan kebijakan hutang sebagai variabel pemoderasi serta diharapkan mampu mendukung teori yang digunakan dalam penelitian ini yaitu Teori Keagensian, Teori Sinyal dan Trade Off Theory. Secara praktis, penelitian ini diharapkan bermanfaat untuk menambah wawasan dan digunakan sebagai bahan pertimbangan dan evaluasi bagi pengguna laporan keuangan, serta dapat mendorong perusahaan untuk meningkatnya nilai perusahaannya.

Teori Keagensian, Teori Sinyal dan Trade Off Theory merupakan grand theory dalam penelitian ini. Teori keagensian menjelaskan bahwa terdapat suatu kontrak di mana satu atau lebih prinsipal menggunakan pihak lain (agent) untuk menjalankan perusahaan. Masalah yang muncul dari perencanaan struktur modal, antara manajer, pemegang saham dan debtholder saling bertentangan sehingga bisa membawa manajer untuk bertindak: 1) mementingkan kepentingan mereka sendiri, dengan memilih proyek suboptimal yang tidak memberikan tingkat imbal hasil yang memadai, tetapi masih dengan risiko yang rendah, sehingga mengabaikan prefensi pemegang saham untuk proyek-proyek berisiko. 2) untuk kepentingan pemegang saham, dengan membuat keputusan investasi yang memaksimalkan nilai ekuitas tidak 
ISSN: 2302-8556

memaksimalkan nilai perusahaan, ketika beroperasi di pasar tidak efisien, dan dapat menyebabkan mereka membuat pilihan suboptimal yang merusak debtholders. Konflik tersebut muncul bersama dengan asimetri informasi, yang dapat mengakibatkan strategi investasi suboptimal yang tidak memaksimalkan nilai perusahaan melainkan hanya menguntungkan kategori tertentu. Investasi yang suboptimal mengakibatkan underinvestment dan overinvestment.

Perencanaan pajak dalam teori keagenan dijelaskan bahwa pemerintah (fiskus) sebagai pihak principal dan manajemen sebagai pihak agent masing-masing memiliki kepentingan yang berbeda dalam hal pembayaran pajak. Perusahaan (agent) berusaha membayar pajak sekecil mungkin karena dengan membayar pajak berarti mengurangi kemampuan ekonomis perusahaan. Dilain pihak, pemerintah (principal) memerlukan dana dari penerimaan pajak untuk membiayai pengeluaran pemerintah. Teori Keagensian menyatakan bahwa Pendelegasian wewenang yang dilakukan pihak prinsipal kepada agen akan menuntut agen untuk memberikan kinerjanya sebaik mungkin agar dapat meningkatkan performa perusahaannya. Oleh karena itu, manajemen berusaha untuk mengelola keuangan perusahaannya dengan baik dan efisien. Salah satu langkah efisiensi yang dilakukan yaitu dengan meminimalkan beban pajak, yang dianggap dapat mengurangi kemampuan ekonomis perusahaan. Sehingga manajemen termotivasi untuk melakukan penghindaran pajak agar dapat meminimalkan beban perusahaan.

Teori Sinyal seperti yang dijelaskan di atas membahas hubungan antara informasi yang diberikan oleh perusahaan dapat memberikan sinyal positif (good 
Ni Wayan Sarasati Pramudia Wanami P. dan Ni Ketut Lely Aryani Merkusiawati. Pengaruh ...

news) atau sinyal negatif (bad news) kepada investor (Prasiwi, 2015). Sinyal tersebut menjadi dasar investor dapat mengetahui prospek masa depan perusahaan sehingga dalam pengambilan keputusan untuk berinvestasi, investor dapat membedakan perusahaan mana yang memiliki nilai perusahaan yang baik, sehingga di masa mendatang dapat memberikan keuntungan bagi investor (Laksitaputri, 2013). Pihak manajer berpandangan praktik penghindaran pajak yang telah dilakukan yang menghasilkan informasi laba setelah pajak yang tinggi diharapkan dapat memberikan sinyal positif yang dapat meningkatkan nilai perusahaan yang ditunjukkan oleh peningkatan harga saham perusahaan dari waktu ke waktu (Simarmata, 2012). Pratik penghindaran pajak dapat dinilai sebagai sinyal positif maupun negatif (Prasiwi, 2015). Penelitian Prasiwi (2015) membuktikan penghindaran pajak dipandang positif jika dipandang sebagai upaya dalam melakukan perencanan pajak dan efisiensi pajak dan resiko deteksinya kecil, dan penghindaran pajak berpengaruh negatif jika dipandang ketidakpatuhan karena tindakan tersebut berisiko menimbulkan biaya yang tinggi nantinya sehingga nilai perusahaan menurun.

Trade Off Theory pertama kali diperkenalkan pada tahun 1963 oleh Modigliani dan Miller dalam sebuah artikel American Economic Review 53 (1963, Juni) yang berjudul Corporate Income Taxes on the Cost of Capital: A Correction. Artikel ini merupakan perbaikan model awal mereka yang sebelumnya memperhitungkan adanya pajak perseroan (akan tetapi tetap mengabaikan pajak perorangan). Selanjutnya model tersebut dikenal dengan sebutan model MM-2 atau model MM dengan pajak perseroan (Brigham dan Ehrhardt, 2005). Teori ini 
ISSN: 2302-8556

menjelaskan ide bahwa berapa banyak utang perusahaan dan berapa banyak ekuitas perusahaan sehingga terjadinya keseimbangan antara biaya dan keuntungan

Berdasarkan model MM-2, dapat dipetik dua hal utama yang berbeda dengan model MM-1 sebelumnya adalah. Dalam model pertama, struktur modal tidak mempengaruhi nilai perusahaan. Dalam kenyataannya, struktur modal mempunyai pengaruh positif terhadap nilai perusahaan: bertambahnya penggunaan utang akan meningkatkan nilai perusahaan, dengan kata lain pajak memberi manfaat dalam pendanaan yang berasal dari utang, sebesar manfaat pajak dari penggunaan utang diperoleh dari beban biaya bunga utang yang dapat diperhitungkan sebagai elemen biaya yang mengurangi besaran laba kena pajak, sedangkan pembayaran dividen tidak dapat diperhitungkan sebagai elemen biaya. Jadi, perusahaan (seperti) menerima subsidi dari pemerintah atas penggunaan utang untuk menambah modal.

Dengan adanya pajak perseroan, diperoleh dua manfaat penggunaan utang yakni: utang merupakan sumber modal yang lebih murah daripada ekuitas, dan biaya bunga menjadi elemen pengurang pajak. Dari model MM-1, diketahui bahwa penghematan dari penggunaan utang yang lebih murah sepenuhnya digantikan oleh peningkatan biaya penggunaan ekuitas. Meskipun demikian, dalam situasi dengan adanya pajak perseroan, keuntungan yang diperoleh perusahaan dari penggunaan utang lebih besar daripada peningkatan biaya ekuitas.

Supporting theory dalam penelitian ini antara lain mengenai balancing theory, penghindaran pajak, nilai perusahaan dan kebijakan hutang. Dewi, dkk., (2014) mengungkapkan bahwa model struktur modal dalam lingkup Balancing Theories 
Ni Wayan Sarasati Pramudia Wanami P. dan Ni Ketut Lely Aryani Merkusiawati. Pengaruh ...

(Myers, 1984 dan Bayles and Diltz, 1994) disebut sebagai teori keseimbangan yaitu dengan menyeimbangkan komposisi hutang dan modal sendiri. Pada intinya teori ini menyeimbangkan antara manfaat dan pengorbanan yang timbul dari akibat penggunaan hutang. Ketika manfaat yang dirasakan masih besar, hutang boleh ditambah. Namun jika pengorbanan karena menggunakan hutang sudah lebih besar maka hutang tidak lagi ditambah. Penghindaran pajak berkenaan dengan pengaturan sesuatu peristiwa sedemikian rupa untuk meminimkan atau menghilangkan beban pajak dengan memperhatikan ada atau tidaknya akibat-akibat pajak yang ditimbulkan. Sehingga penghindaran pajak tidak merupakan pelanggaran atas perundang-undangan perpajakan atau secara etik tidak dianggap salah dalam rangka usaha wajib pajak untuk mengurangi, menghindari, meminimumkan atau meringankan beban pajak dengan cara-cara yang dimungkinkan oleh undang-undang pajak. Definisi yang lebih luas tentang penghindaran pajak menurut Prasiwi (2015) adalah merupakan rangkaian strategi perencanaan pajak, yang secara ekonomis berusaha memaksimalkan penghasilan setelah pajak (after tax return) untuk dibagikan kepada investor maupun untuk diinvestasikan kembali oleh perusahaan.

Perusahaan pada umumnya memiliki tujuan jangka panjang adalah mengoptimalkan nilai perusahaan (Dewi dkk., 2014). Pengoptimalan nilai perusahaan bertujuan untuk meningkatkan kesejahteraan pemilik perusahaan, karena semakin meningkat nilai perusahaan dan meningkatkan kesejahteraan pemilik perusahaan, maka dari itu pemilik perusahaan berupaya bekerja keras untuk menggunakan berbagi intensif untuk memaksimalkan nilai perusahaan dengan cara mendorong manajer 
ISSN: 2302-8556

(Prasiwi, 2015).Peningkatan nilai perusahaan ditunjukkan dengan peningkatan nilai saham di pasar modal, dimana semakin meningkat nilai perusahaan akan semakin meningkat pula harga saham perusahaan tersebut (Dewi dkk., 2014). Meningkatnya harga saham maka akan meningkat pula kesejahteraan pemegang saham. Perusahaan dalam mendanai kegiatan operasionalnya memiliki dua alternatif pendanaan yaitu pendanaan internal dan pendanaan eksternal yang dalam hal ini kebijakan hutang termasuk sebagai kebijakan pendanaan perusahaan yang bersumber dari eksternal. Kebijakan hutang adalah kebijakan yang diambil oleh pihak manajemen dalam rangka memeroleh sumber pembiayaan bagi perusahaan sehingga dapat digunakan untuk membiayai aktivitas operasional perusahaan. Selain itu kebijakan hutang perusahaan juga berfungsi sebagai alat monitoring terhadap tindakan manajer yang dilakukan dalam pengelolaan perusahaan.

Teori keagensian dapat menjelaskan peran penghindaran pajak pada nilai perusahaan. Pendelegasian wewenang yang dilakukan pihak prinsipal kepada agen akan menuntut agen untuk memberikan kinerjanya sebaik mungkin agar dapat meningkatkan performa perusahaannya. Oleh karena itu, manajemen berusaha untuk mengelola keuangan perusahaannya dengan baik dan efisien. Salah satu langkah efisiensi yang dilakukan yaitu dengan meminimalkan beban pajak, yang dianggap dapat mengurangi kemampuan ekonomis perusahaan. Sehingga manajemen termotivasi untuk melakukan penghindaran pajak agar dapat meminimalkan beban perusahaan, dengan begitu diharapkan laba perusahaan akan meningkat yang dapat berdampak pada peningkatan nilai perusahaan. Adapun penelitian sebelumnya yang 
Ni Wayan Sarasati Pramudia Wanami P. dan Ni Ketut Lely Aryani Merkusiawati. Pengaruh ...

dilakukan oleh Prasiwi (2015), Anggoro \& Septiani (2015), Kurniawan \& Syafruddin (2017) mendapatkan hasil bahwa penghindaran pajak berpengaruh positif pada nilai perusahaan. Berdasarkan uraian tersebut, maka rumusan hipotesis pertama dalam penelitian ini.

$\mathrm{H}_{1}$ : Penghindaran pajak berpengaruh positif pada nilai perusahaan.

Berdasrkan teori Modigliani-Miller (MM Theory), perusahaan yang menggunakan hutang sebagai sumber pendanaan akan semakin sejahtera. Hal ini disebabkan karena biaya atas bunga hutang dapat dikurangkan dari penghasilan kena pajak sehingga penggunaan hutang dapat meningkatkan nilai perusahaan karena biaya bunga hutang adalah biaya yang mengurangi pembayaran pajak. Penghindaran pajak dilakukan dengan memanfaatkan deductible expense yaitu dengan beban bunga sebagai pengurang pajak, hal tersebut dapat berpengaruh terhadap biaya hutang setelah pajak yang lebih rendah dan tingkat pengembalian yang lebih tinggi kepada perusahaan, dan juga mengurangi konflik keagenan dalam perusahaan. Teori sinyal dalam hal menilai struktur modal suatu perusahaan, investor akan memandang hutang sebagai sinyal dari nilai perusahaan. Menurut Brigham dan Houston (2011) dalam Arifin (2017) menyatakan bahwa pengumuman penawaran saham biasanya dianggap sebagai suatu sinyal bahwa prospek perusahaan kurang cerah menurut penilaian manajemennya.

Kebijakan hutang juga dianggap sebagai salah satu cara yang dapat digunakan untuk melindungi penghasilan perusahaan dari besarnya pajak penghasilan dan dapat mengoptimalkan laba sehingga akan meningkatkan nilai perusahaan. Oleh karena itu, 
penelitian ini menggunakan hipotesis bahwa kebijakan hutang dapat memperkuat pengaruh penghindaran pajak pada nilai perusahaan.

$\mathrm{H}_{2}$ : Kebijakan hutang dapat memperkuat pengaruh penghindaran pajak pada nilai perusahaan.

\section{METODE PENELITIAN}

Penelitian ini dilakukan pada perusahaan sektor manufaktur yang terdaftar di Bursa Efek Indonesia (BEI) pada tahun 2013 hingga 2017. Jenis data pada penelitian ini adalah data kuantitatif, yaitu angka-angka yang terdapat dalam laporan keuangan perusahaan sektor manufaktur yang terdaftar di BEI tahun 2013-2017. Serta, data kualitatif yang berupa nama-nama perusahaan sektor manufaktur yang terdaftar di BEI tahun 2013-2017. Sumber data penelitian ini yaitu data sekunder berupa laporan keuangan tahunan perusahaan sektor manufaktur yang terdaftar di BEI tahun 20132017 yang diakses pada www.idx.co.id. Variabel dependen dalam penelitian ini yaitu nilai perusahaan yang diproksikan dengan Tobin's Q. Variabel independen pada penelitian ini adalah agresivitas pajak yang diproksikan dengan Current Effective Tax Rate (ETR). Variabel moderasi penelitian ini adalah ukuran perusahaan yang diproksikan dengan Debt to Equity Ratio (DER).

nilai perusahaan diukur dengan menggunakan Rasio Torbin Q. Rasio ini dipilih karena dapat menjelaskan berbagai fenomena dalam kegiatan perusahaan, misalnya terjadi perbedaan crossectional dalam pengambilan keputusan investasi dan diversifikasi, hubungan antara kepemilikan saham manajemen dan nilai perusahaan, 
Ni Wayan Sarasati Pramudia Wanami P. dan Ni Ketut Lely Aryani Merkusiawati. Pengaruh ...

hubungan antara kinerja manajemen dengan keuntungan dalam akuisisi, dan kebijakan pendanaan, dividen, dan kompensasi (Sukamulja, 2004 dalam Aziza 2016).

$$
\begin{aligned}
& \text { Tobins } \mathrm{Q}=(\mathrm{EMV}+\mathrm{D}) /(\mathrm{EBV}+\mathrm{D}) \\
& \mathrm{D}=(\mathrm{AVCL}-\mathrm{AVCA})+\mathrm{AVLTD} \ldots \ldots
\end{aligned}
$$

Keterangan:

EMV = Equity Market Value

$\mathrm{EBV}=$ Equity Book Value

$\mathrm{D} \quad=$ Debt

AVCL $=$ Accounting value of the firm's Current Liabilities. = Short Term Debt + Taxes Payable.

AVLTD = Accounting value of the firm's Long Term Debt. = Long Term Debt.

AVCA = Accounting value of the firm's Current Assets.

Penghindaran pajak berkenaan dengan pengaturan sesuatu peristiwa sedemikian rupa untuk meminimkan atau menghilangkan beban pajak dengan memperhatikan ada atau tidaknya akibat-akibat pajak yang ditimbulkan. Sehingga penghindaran pajak tidak merupakan pelanggaran atas perundang-undangan perpajakan atau secara etik tidak dianggap salah dalam rangka usaha wajib pajak untuk mengurangi, menghindari, meminimumkan atau meringankan beban pajak dengan cara-cara yang dimungkinkan oleh undang-undang pajak.

$$
\text { Current } \mathrm{ETR}=\frac{\text { Current } \text { Tax Expense }}{\text { Pretax Income }}
$$

Keterangan:

Current ETR : Effective tax rate berdasarkan jumlah pajak penghasilan badan yang dibayarkan perusahaan pada tahun berjalan,

Current Tax Expense : Jumlah pajak penghasilan badan yang dibayarkan perusahaan pada tahun tersebut berdasarkan laporan keuangan perusahaan.

Pretax Income : Pendapatan sebelum pajak untuk perusahaan pada tahun tersebut berdasarkan laporan keuangan perusahaan. 
Banyak cara yang dapat digunakan untuk menghitung kebijakan hutang salah satunya dihitung dengan Debt to equity ratio (DER) adalah rasio yang menggambarkan perbandingan hutang dan ekuitas dalam pendanaan perusahaan dan menunjukan kemampuan modal sendiri perusahaan tersebut untuk memenuhi seluruh kewajibannya (Pittman and Fortin, 2004) dalam Masri \& Martani (2014).

Debt to Equity Ratio $=\frac{\text { Total Hutang }}{\text { Total Ekuitas }}$

Populasi dalam penelitian ini adalah seluruh perusahaan manufaktur yang telah terdaftar di Bursa Efek Indonesia pada tahun 2013-2017. Sampel yang yang digunakan adalah perusahaan sektor manufaktur yang telah terdaftar di BEI pada tahun 2013-2017 yang sesuai dengan kriteria pemilihan sampel pada penelitian ini. Penentuan sampel dalam penelitian ini menggunakan metode purposive sampling. Metode pengumpulan data yang digunakan dalam penelitian ini yaitu metode observasi non partisipan. Teknik analisis data penelitian ini menggunakan uji Moderated Regression Analysis (MRA), yang persamaannya sebagai berikut.

$$
\mathrm{Y}=\alpha+\beta 1 \mathrm{X}_{1}+\beta 2 \mathrm{X}_{2}+\beta 3 \mathrm{X}_{1} * \mathrm{X}_{2}+\mathrm{e} 2
$$

Keterangan:

$\alpha=$ konstanta

$\mathrm{X}_{1}=$ Penghindaran Pajak $\quad \mathrm{Y}=$ Nilai Perusahaan

$\mathrm{e}=$ standar eror

$\mathrm{X}_{2}=$ Kebijakan Hutang

$\mathrm{X}_{1} * \mathrm{X}_{2}=$ Interaksi penghindaran pajak dengan kebijakan hutang 
Ni Wayan Sarasati Pramudia Wanami P. dan Ni Ketut Lely Aryani Merkusiawati. Pengaruh ...

\section{HASIL DAN PEMBAHASAN}

Jumlah keseluruhan sampel yang diperoleh dalam penelitian ini adalah sebanyak 182 perusahaan manufaktur dengan jumlah tahun pengamatan dalam penelitian ini adalah 5 tahun. Statistik deskriptif dalam penelitian ini menjelaskan karakteristik variabel penelitian, yaitu jumlah pengamatan, nilai minimum, nilai maksimum, nilai rata-rata (mean), dan standar deviasi pada variabel-variabel yang diteliti, yaitu agresivitas pajak, kebijakan hutang dan nilai perusahaan. Hasil statistiK deskriptif penelitian ini dapat dilihat pada Tabel 2 berikut.

\begin{tabular}{lccccc}
\multicolumn{7}{c}{ Tabel 2. } \\
& Hasil Statistik Deskriptif & \\
\hline & $\mathrm{N}$ & Minimum & Maximum & Mean & Std. Deviation \\
\hline Tax Avoidance & 182 & 0,0002 & 1,3817 & 0,261193 & 0,1657290 \\
Kebijakan Hutang & 182 & 0,0387 & 608,5751 & 13,333482 & 74,3030916 \\
Nilai Perusahaan & 182 & $-40,8259$ & 337,1820 & 7,983252 & 30,0481912 \\
Valid N (listwise) & 182 & & & & \\
\hline Sumber: Data diolah, 2018 & & & &
\end{tabular}

Berdasarkan Tabel 2 tersebut, diketahui variabel nilai perusahaan yang diukur menggunakan rasio Tobin's $\mathrm{Q}$ memiliki nilai minimum sebesar $-40,8259$, nilai maksimum sebesar 337,1820 dan nilai mean sebesar 7,9832. Variabel penghindaran pajak yang diukur dengan proksi Current Effective Tax Rate (ETR) memperoleh nilai minimum yaitu sebesar 0,0002 , nilai maksimum ETR sebesar 1,3817, serta nilai ratarata (mean) 0,2611. Variabel kebijakan hutang yang diproksikan dengan Debt to Equity Ratio (DER) memiliki nilai minimum 0,0387, nilai maksimum 608,5751 dan nilai rata-rata (mean) 13,3334. Uji asumsi klasik dilakukan agar data yang digunakan 
ISSN: 2302-8556

E-Jurnal Akuntansi Universitas Udayana

Vol.27.1.April (2019):446-474

dalam pengujian hipotesis, bebas dari asumsi klasik untuk mendapatkan model yang layak diteliti. Hasil dari uji asumsi klasik disajikan pada Tabel 3 berikut.

Tabel 3. Rekapitulasi Hasil Uji Asumsi Klasik

\begin{tabular}{ccccc}
\hline $\begin{array}{c}\text { Uji Normalitas } \\
\begin{array}{c}\text { Asymp. Sig. (2- } \\
\text { tailed) }\end{array}\end{array}$ & $\begin{array}{c}\text { Uji } \\
\text { Autokorelasi } \\
\text { (Durbin } \\
\text { Watson) }\end{array}$ & Variabel & $\begin{array}{c}\text { Uji } \\
\text { Heteroskedastisitas } \\
\text { (sig) }\end{array}$ & $\begin{array}{c}\text { Multikoleniaritas } \\
\text { (VIF) }\end{array}$ \\
\hline \multirow{2}{*}{0,60} & & Penghindaran & & 1,132 \\
& \multirow{2}{*}{1,843} & Pajak & 0,561 & 1,373 \\
& & Kebijakan & 0,381 & \\
& & Hutang & 0,509 & \\
\hline
\end{tabular}

Sumber: Data diolah, 2018

Berdasarkan Tabel 3, dapat dilihat bahwa nilai Asymp. Sig (2-tailed) 0,060 lebih besar dari level of significant, yaitu 5 persen $(0,05)$, sehingga data yang diuji sudah menyebar normal atau berdistribusi normal. Pengujian autokorelasi dilakukan melalui Durbin-Watson test menunjukkan bahwa pada persamaan regresi memiliki nilai Durbin-Watson sebesar 1,843, Dengan demikian hasil uji autokorelasi dengan kriteria du $<$ DW $<4$-du adalah 1,7241 $<1,843<2,209$, maka dapat disimpulkan bahwa model regresi yang dibuat tidak mengandung gejala autokorelasi. Tabel 3 menunjukkan bahwa nilai signifikansi penghindaran pajak $\left(X_{1}\right)$ sebesar 0,561 , Kebijakan hutang $\left(\mathrm{X}_{2}\right)$ sebesar 0,381, dan Interaksi antara penghindaran pajak dengan Kebijakan hutang $\left(\mathrm{X}_{1} . \mathrm{X}_{2}\right)$ sebesar 0,509 . Hasil uji tersebut memiliki nilai yang lebih besar dari $\alpha=0.05$. Oleh karena itu, dapat disimpulkan bahwa tidak terjadi heteroskedastisitas. Untuk mendeteksi ada atau tidaknya korelasi antar variabel bebas dapat dilihat dari nilai tolerance dan nilai variance inflation factor (VIF). Jika nilai tolerance lebih dari $10 \%$ atau VIF Kurang dari 10, maka dapat dikatakan model telah 
Ni Wayan Sarasati Pramudia Wanami P. dan Ni Ketut Lely Aryani Merkusiawati. Pengaruh ...

bebas dari multikolinearitas, dapat dilihat bahwa nilai VIF dari seluruh variabel tersebut menunjukkan bahwa nilai VIF lebih kecil dari 10 yang berarti model persamaan regresi bebas dari multikolinearitas.

Setelah data lolos uji asumsi klasik, maka selanjutnya adalah melakukan uji Moderated Regression Analysis (MRA) untuk mengetahui pengaruh penghindaran pajak pada nilai perusahaan dan pengaruh penghindaran pajak pada nilai perusahaan dengan kebijakan hutang sebagai variabel pemoderasi di perusahaan sektor manufaktur yang terdaftar di BEI tahun 2013 hingga 2017. Hasil uji MRA dalam penelitian ini dapat dilihat pada Tabel 4 berikut.

\section{Tabel 4.}

\section{Hasil Uji Moderated Regression Analysis (MRA)}

\begin{tabular}{|c|c|c|c|c|c|c|}
\hline \multicolumn{2}{|c|}{ Model } & \multicolumn{2}{|c|}{$\begin{array}{c}\text { Unstandardized } \\
\text { Coefficients }\end{array}$} & \multirow{2}{*}{$\begin{array}{c}\text { Standardized } \\
\text { Coefficients } \\
\text { Beta }\end{array}$} & \multirow[t]{2}{*}{$\mathrm{t}$} & \multirow[t]{2}{*}{ Sig. } \\
\hline & & $\mathrm{B}$ & Std. Error & & & \\
\hline 1 & (Constant) & -.184 & .070 & & $\begin{array}{c}- \\
2.623\end{array}$ & .009 \\
\hline & Tax Avoidance & .225 & .070 & .242 & 3.196 & .002 \\
\hline & Kebijakan Hutang & 227 & .077 & 247 & 2.963 & .003 \\
\hline & Interaksi X1.X2 & 209 & .078 & .232 & 2.680 & .008 \\
\hline & & & & & & 0,101 \\
\hline & ted R Square & & & & & 0,086 \\
\hline & & & & & & 6,654 \\
\hline & ikansi F & & & & & 0,000 \\
\hline
\end{tabular}

Sumber: Data diolah, 2018

Berdasarkan Tabel 4 di atas, maka persamaan MRA pada penelitian ini sebagai berikut.

$$
Y=-0,184+0,225 X_{1}+0,227 X_{2}+0,209 X_{1} X_{2}+e_{3}
$$

Persamaan tersebut dapat diintepretasikan sebagai berikut 1) Nilai konstanta $(\alpha)$ sebesar $-0,184$ berarti apabila variabel penghindaran pajak, kebijakan hutang, serta interaksi antara penghindaran pajak dan kebijakan hutang bernilai konstan, maka nilai perusahaan (Y) 
ISSN: 2302-8556

E-Jurnal Akuntansi Universitas Udayana

Vol.27.1.April (2019):446-474

akan menurun sebesar 0,184 satuan. 2) Nilai koefisien regresi $\left(\beta_{1}\right)$ dari penghindaran pajak $\left(\mathrm{X}_{1}\right)$ yaitu 0,225 memiliki arti bahwa ketika nilai penghindaran pajak yang diproksikan dengan Current ETR meningkat 1 satuan, maka nilai perusahaan (Y) meningkat sebesar 0,225 satuan, dengan asumsi variabel lainnya konstan. 3) Nilai koefisien regresi $\left(\beta_{2}\right)$ kebijakan hutang $\left(\mathrm{X}_{2}\right)$ sebesar 0,227 berarti jika kebijakan hutang meningkat 1 satuan maka nilai perusahaan (Y) meningkat sebesar 0,227 satuan, dengan asumsi variabel lainnya konstan. 4) Nilai koefisien regresi interaksi $\left(\beta_{3}\right)$ dari penghindaran pajak dan kebijakan hutang $\left(\mathrm{X}_{1} \mathrm{X}_{2}\right)$ sebesar 0,209 memiliki arti bahwa ketika nilai interaksi meningkat sebesar 1 satuan, maka nilai perusahaan (Y) meningkat sebesar 0,209 dengan variabel independen lainnya konstan.

Berdasarkan Tabel 4, hasil uji koefisien determinasi $\left(\mathrm{R}^{2}\right)$ menunjukkan besarnya nilai $\mathrm{R}^{2}$ adalah sebesar 0,101 . Ini berarti variasi Nilai perusahaan dapat dipengaruhi secara signifikan oleh variabel penghindaran pajak, kebijakan hutang, dan variabel interaksi antara penghindaran pajak dengan kebijakan hutang sebesar 10,1 persen sedangkan sisanya sebesar 89,9 persen dijelaskan oleh faktor-faktor lain. Hasil uji F (Ftest) menunjukkan bahwa nilai signifikansi P value 0,000 yang lebih kecil dari $\alpha=$ 0,05 , ini berarti model yang digunakan pada penelitian ini adalah layak. Hasil ini memberikan makna bahwa seluruh variabel independen yaitu penghindaran pajak, kebijakan hutang, dan variabel interaksi antara penghindaran pajak dengan kebijakan hutang mampu memprediksi atau menjelaskan fenomena nilai perusahaan pada seluruh sampel perusahaan manufaktur di BEI tahun 2013-2017. 
Ni Wayan Sarasati Pramudia Wanami P. dan Ni Ketut Lely Aryani Merkusiawati. Pengaruh ...

Hasil uji hipotesis (uji t) pada hipotesis pertama berdasarkan Tabel 4, menunjukan bahwa hasil analisis pengaruh penghindaran pajak pada nilai perusahaan diperoleh nilai signifikansi sebesar 0,002 dengan nilai koefisien regresi sebesar 0,225. Nilai Signifikansi $0,002<0,050$ mengindikasikan bahwa $\mathrm{H}_{0}$ ditolak dan $\mathrm{H}_{1}$ diterima. Hasil ini mempunyai arti bahwa penghindaran pajak berpengaruh positif dan signifikan pada nilai perusahaan. Hal ini menunjukan bahwa semakin tinggi penghindaran pajak yang dilakukan perusahaan akan meningkatkan nilai perusahaan karena dapat meningkatkan kesejahteraan investor, dengan cara mentransfer kekayaan dari pemerintah ke pemegang saham. Hasil penelitian ini sejalan dengan penelitian yang dilakukan oleh Kurniawan \& Syafruddin, (2017), dan Anggoro \& Septiani (2015) yang menyatakan bahwa penghindaran pajak yang dilakukan perusahaan memiliki pengaruh yang positif pada nilai perusahaan.

Hasil penelitian ini mendukung Teori Agensi yang menyatakan bahwa Pendelegasian wewenang yang dilakukan pihak prinsipal kepada agen akan menuntut agen untuk memberikan kinerjanya sebaik mungkin agar dapat meningkatkan performa perusahaannya. Oleh karena itu, manajemen berusaha untuk mengelola keuangan perusahaannya dengan baik dan efisien. Salah satu langkah efisiensi yang dilakukan yaitu dengan meminimalkan beban pajak, yang dianggap dapat mengurangi kemampuan ekonomis perusahaan. Sehingga manajemen termotivasi untuk melakukan penghindaran pajak agar dapat meminimalkan beban perusahaan, dengan begitu diharapkan laba perusahaan akan meningkat yang dapat berdampak pada peningkatan nilai perusahaan. 
ISSN: 2302-8556

Hasil penelitian ini juga mendukung Teori Sinyal dalam lingkup pajak, pihak manajer berpandangan praktik penghindaran pajak yang telah dilakukan yang menghasilkan informasi laba setelah pajak yang tinggi diharapkan dapat memberikan sinyal positif yang dapat meningkatkan nilai perusahaan yang ditunjukkan oleh peningkatan harga saham perusahaan dari waktu ke waktu. Kementrian Keuangan Republik Indonesia pada tahun 2015 telah mengeluarkan PMK-169/PMK.010/2015 tentang penentuan besarnya perbandingan antara htang dan modal perusahaan yang mengakui beban bunga sebagai deductible expense. Peraturan ini mengatur bahwa bunga hutang yang dapat diakui sebagai biaya adalah sebesar bunga atas hutang yang perbandingannya terhadap modal, yaitu setinggi-tingginya empat banding satu (4:1). Pemerintah di Indonesia memberikan suatu cara yang legal bagi perusahaan dalam melakukan efisiensi pajak melalui peraturan - peraturan perpajakan yang dikeluarkan. Peraturan - peraturan tersebut merupakan celah - celah pajak yang dapat dimanfaatkan oleh perusahaan untuk meminimalkan beban pajaknya, selain itu celah dalam melakukan efisiensi pajak yang dapat dilakukan secara legal memberikan dampak positif bagi perusahaan jika dapat memanfaatkannya secara baik.

Cara yang legal dalam melakukan efisiensi pajak akan dipandang positif oleh stakeholder perusahaan karena dapat meningkatkan kesejahteraan mereka, dengan cara mentransfer kekayaan dari pemerintah ke pemegang saham sehingga berdampak pada meningkatnya nilai perusahaan (Chen et al., 2016). Oleh karena itu, meskipun penghindaran pajak merupakan tindakan yang juga memiliki risiko, namun bila dilakukan sesuai dengan peraturan yang ada dan dilakukan dengan cermat sebagai 
Ni Wayan Sarasati Pramudia Wanami P. dan Ni Ketut Lely Aryani Merkusiawati. Pengaruh ...

upaya melakukan tax planning dan efisiensi pajak hal tersebut akan bermanfaat bagi perusahaan. Maka dapat disimpulkan tindakan penghindaran pajak yang dilakukan perusahaan dapat memengaruhi dan berdampak positif pada nilai perusahaan.

Pada hipotesis kedua, hasil uji hipotesis (uji t) berdasarkan Tabel 4 menunjukan bahwa kebijakan hutang dapat memerkuat pengaruh penghindaran pajak pada nilai perusahaan. Hasil penelitian menunjukkan bahwa kebijakan hutang yang diproksikan dengan debt to equity ratio (DER) dapat memoderasi dan memerkuat pengaruh penghindaran pajak pada nilai perusahaan sesuai dengan hasil pengujian hipotesis dengan menggunakan uji t, diketahui bahwa variabel kebijakan hutang menghasilkan nilai t sebesar 2,680 dengan nilai signifikansi 0,008 sehingga H2 diterima, selain itu berdasarkan hasil uji analisis regresi moderasi, pada Tabel 4.8 menunjukkan nilai koefisien regresi penghindaran pajak $\left(\beta_{1}\right)$ positif signifikan dan variabel interaksi antara penghindaran pajak dengan kebijakan hutang $\left(\beta_{3}\right)$ positif signifikan, maka variabel kebijakan hutang $\left(\mathrm{X}_{2}\right)$ merupakan variabel moderasi yang memerkuat pengaruh penghindaran pajak pada nilai perusahaan.

Variabel kebijakan hutang $\left(\mathrm{X}_{2}\right)$ merupakan variabel moderasi yang memperkuat pengaruh penghindaran pajak pada nilai perusahaan. Dengan mengidentifikasi koefisien regresi penghindaran pajak $\left(\beta_{1}\right)$ dan koefisien interaksi antara penghindaran pajak dengan kebijakan hutang $\left(\beta_{3}\right)$ dalam persamaan regresi moderasi dihasilkan koefisien $\beta_{1}$ dan koefisien $\beta_{3}$ yang signifikan secara statistika sehingga jenis regresi yang dihasilkan adalah Quasi moderasi merupakan variabel yang memoderasi hubungan antara variabel independen dan variabel dependen di 
ISSN: 2302-8556

E-Jurnal Akuntansi Universitas Udayana

Vol.27.1.April (2019):446-474

mana variabel moderasi semu berinteraksi dengan variabel independen sekaligus menjadi variabel independen.

Variabel kebijakan hutang dapat memerkuat pengaruh penghindaran pajak pada nilai perusahaan dikarenakan stakeholder terutama investor juga mempertimbangkan bagaimana cara tindakan penghindaran pajak dilakukan oleh manajemen, salah satunya adalah dengan cara menggunakan biaya hutang sebagai beban pengurang pajak, sehingga muncul kecenderungan bagi perusahaan untuk melakukan pembiayaan kembali hutang pada tahun selanjutnya untuk mendapatkan manfaat dari insentif pajak yang lebih besar (Midiastuty dkk., 2017).

Teori Sinyal dalam lingkup pajak menyatakan bahwa tindakan atau karakter manajemen yang memilih menggunakan hutang sebagai modal dalam perusahaannya akan memberikan sinyal bahwa bebijakan hutang yang diterapkan dianggap sebagai salah satu cara yang dapat digunakan untuk melindungi penghasilan perusahaan dari besarnya pajak penghasilan, hal ini sejalan dengan teori Modigliani-Miller dalam Trade Off Theory, perusahaan yang menggunakan hutang sebagai sumber pendanaan akan semakin sejahtera. Hal ini disebabkan karena biaya atas bunga hutang dapat dikurangkan dari penghasilan kena pajak sehingga penggunaan hutang dapat meningkatkan nilai perusahaan karena biaya bunga hutang adalah biaya yang mengurangi pembayaran pajak (Antwi et al., 2012).

Tujuan dari penghindaran pajak adalah untuk mengurangi beban pajak, sehingga laba perusahaan dapat lebih maksimal, hal tersebut akan menunjukan kinerja perusahaan yang baik. Salah satu indikator dari kinerja perusahaan yang baik 
Ni Wayan Sarasati Pramudia Wanami P. dan Ni Ketut Lely Aryani Merkusiawati. Pengaruh ...

adalah dengan meningkatnya nilai perusahaan. Keputusan pendanaan menggunakan hutang yang dilihat dari kebijakan hutang suatu perusahaan dapat dijadikan sebagai sumber pendanaan dan insentif pajak yang dapat mengoptimalkan laba dapat meningkatkan nilai perusahaan, oleh sebab itu kebijakan hutang dapat memerkuat pengaruh positif penghindaran pajak pada nilai perusahaan.

\section{SIMPULAN}

Berdasarkan hasil analisis dan pembahasan, maka dapat disimpulkan penghindaran pajak berpengaruh positif pada nilali perusahaan. Hal ini menunjukan bahwa semakin tinggi penghindaran pajak yang dilakukan perusahaan akan meningkatkan nilai perusahaan karena dapat meningkatkan kesejahteraan investor, dengan cara mentransfer kekayaan dari pemerintah ke pemegang saham. Kebijakan hutang perusahaan dapat meperkuat pengaruh penghindaran pajak pada nilai perusahaan. Hal ini dikarenakan tindakan atau karakter manajemen yang memilih menggunakan hutang sebagai modal dalam perusahaannya dapat digunakan untuk melindungi penghasilan perusahaan dari besarnya pajak penghasilan sehingga dapat mengoptimalkan laba dan meningkatkan nilai perusahaan.

Saran yang dapat diajukan untuk penelitian selanjutnya, yakni. Bagi perusahaan agar manajemen perusahaan bisa merancang mekanisme pelaksanaan kelanjutan perusahaannya dengan baik, dengan tidak melakukan perencanaan pajak yang ilegal sehingga perusahaan tidak melakukan kecurangan pajak (tax evasion) yang dapat merugikan negara dan dapat memburukkan nama dan reputasi perusahaan 
ISSN: 2302-8556

E-Jurnal Akuntansi Universitas Udayana

Vol.27.1.April (2019):446-474

tersebut di mata publik. Bagi setiap wajib pajak, khususnya wajib pajak badan agar dapat mengefisienkan beban pajak yang masih berada dalam batas kebiasaan bisnis yang baik tanpa melanggar peraturan perpajakan. Bagi investor hendaknya mempertimbangkan kebijakan hutang (DER) perusahaan, dengan menekankan bagaimana penggunaan hutang tersebut serta mempertimbangkan manajemen pajak yang dilakukan oleh perusahaan dengan menganalisis informasi yang ada di dalam catatan atas laporan keuangan. Bagi pemerintah agar membuat peraturan perpajakan yang jelas mengenai kelegalan dari celah- celah peraturan untuk melakukan kegiatan manajemen perpajakan tersebut sehingga dapat meminimalisir perbedaan pendapat antara fiskus dan wajib pajak. Selain itu, perlu juga tindakan monitoring dan pengawasan dari pemerintah terhadap perusahaan-perusahaan yang melaporkan kewajiban perpajakannya.

\section{REFERENSI}

Ampriyanti, M., \& Lely, K. (2016). Pengaruh Tax Avoidance Jangka Panjang terhadap Nilai Perusahaan dengan Karakter Eksekutif Sebagai Variabel Pemoderasi. E-Jurnal Akuntansi Universitas Udayana, 16(03), 2231-2259.

Anggoro, S. T., \& Septiani, A. (2015). Analisis Pengaruh Perilaku Penghindaran Pajak terhadap Nilai Perusahaan dengan Transparansi Sebagai Variabel Moderating. Diponegoro Journal of Accounting, 4, 1-10. Diambil dari http://ejournal-s1.undip.ac.id/index.php/accounting\%0A

Antwi, S., Fiifi, E., \& Zhao, X. (2012). Capital Structure and Firm Value : Empirical Evidence from Ghana. International Journal of Business and Social Science, 3(22), 103-111.

Arifin, F. (2017). Pengaruh Risiko Bisnis, Beban Pajak dan Pertumbuhan Penjualan terhadap Nilai Perusahaan dengan Struktur Modal Sebagai Intervening pada 
Ni Wayan Sarasati Pramudia Wanami P. dan Ni Ketut Lely Aryani Merkusiawati. Pengaruh ...

Perusahaan Properti Yang Tercatat di BEI. Jurnal Akuntanika, 3(2), 104-124.

Aziza, K. (2016). Pengaruh Penghindaran Pajak Terhadap Biaya Hutang Dengan Kepemilikan Institusional Sebagai Variabel Moderasi Pada Perusahaan Manufaktur Yang Terdaftar Di Bursa Efek Indonesia Periode 2013-2015. Historia Social, 1(86), 71-90. https://doi.org/10.1145/2505515.2507827

Cahyono, D. D., Andini, R., \& Raharjo, K. (2016). Pengaruh Komite Audit, Kepemilikan Institusional, Dewan Komisaris, Ukuran Perusahaan (Size), Leverage (DER) dan Profitabilitas (ROA) terhadap Tindakan Penghindaran Pajak (Tax Avoidance) pada Perusahaan Perbankan yang Listing BEI Periode Tahun 2011-2013. Journal of Accounting, 2(2), 45-46.

Chen, Z., Cheok, C. K., \& Rasiah, R. (2016). Corporate Tax Avoidance and Performance: Evidence from China' $\mathrm{s}$ Listed Companies. Institutions and Economies, 8, 61-83.

Dewi, I. R., Handayani, S. R., \& Nuzula, N. F. (2014). Pengaruh Struktur Modal Terhadap Nilai Perusahaan (Studi pada Sektor Pertambangan yang Terdaftar di BEI Periode 2009-2012). Jurnal Administrasi Bisnis (JAB), 17(1), 1-9.

Endraswati, H. (2013). Pengaruh Struktur Kepemilikan dan Kebijakan Dividen Terhadap Nilai Perusahaan dengan Kebijakan Hutang Sebagai Variabel Moderating Pada Perusahaan Di BEI. STAIN Salatiga, 1-19.

Horne, J. C., \& John M Wachowicz. (2009). Fundamentals of Financial Management (13 ed.). Harlow: FT Prentice Hall.

Kementrian Keuangan Republik Indonesia. PMK-169/PMK.010/2015 Penentuan Besarnya Perbandingan Antara Utang dan Modal Perusahaan, Pub. L. No. 169/PMK.010/2015 (2015). Indonesia.

Kementrian Keuangan Republik Indonesia. (2016). APBN 2016. Diambil 27 Juni 2018, dari www.kemenkeu.go.id

Kementrian Keuangan Republik Indonesia. (2018). Keterangan Pers Penerimaan Perpajakan Hingga Akhir Februari 2018. Jakarta. Diambil dari www.kemenkeu.go.id

Kurniawan, A. F., \& Syafruddin, M. (2017). Pengaruh Penghindaran Pajak terhadap Nilai Perusahaan dengan Variabel Moderasi Transparansi. Diponegoro Journal of Accounting, 6(4), 1-10. Diambil dari http://ejournals1.undip.ac.id/index.php/accounting 
ISSN: 2302-8556

E-Jurnal Akuntansi Universitas Udayana

Vol.27.1.April (2019):446-474

Laksitaputri, I. M. (2013). Analisis Faktor-Faktor Yang Mempengaruhi Nilai Perusahaan dengan Profitabilitas Sebagai Variabel Intervening ( Studi pada Perusahaan Manufaktur Yang Terdaftar di Bursa Efek Indonesia Periode 20082010). Junal Bisnis Strategi, 21(2), 1-17.

Masri, I., \& Martani, D. (2014). Tax avoidance behaviour towards the cost of debt. International Journal Trade and Global Markets, 7(3), 235-249. https://doi.org/10.1504/IJTGM.2014.064911

Midiastuty, P. P., Suranata, E., \& Kristina. (2017). Pengaruh Penghindaran Pajak Terhadap Struktur Modal Perusahaan. In Simposium Nasional Akuntansi XX. Jember. https://doi.org/https://dx.doi.org/10.1111/febs.12555

Partha, I. G. A., \& Noviari, N. (2016). . Pengaruh Penghindaran Pajak Jangka Panjang pada Nilai Perusahaan dengan Transparansi Informasi Sebagai Variabel Pemoderasi. E-Jurnal Akuntansi Universitas Udayana, 14(3), 2336-2362. https://doi.org/10.1016/S0025-7753(01)71902-1

Prasiwi, K. W. (2015). Pengaruh Penghindaran Pajak Terhadap Nilai Perusahaan: Transparansi Informasi Sebagai Variabel Pemoderasi. Skripsi Fakultas Ekonomika dan Bisnis Universitas Diponegoro. Universitas Diponegoro. https://doi.org/10.1007/s11837-018-2742-2

Simarmata, W. (2012). Almanak HKBP 2012. Medan: HKBP.

Tarihoran, A. (2016). Pengaruh Penghindaran Pajak dan Leverage terhadap Nilai Perusahaan dengan Transparansi Perusahaan Sebagai Variabel Moderasi. Jurnal Wira Ekonomi Mikroskil, 6(2), 149-164. 